\title{
Natural permanent pasture silage evaluation from one or two cuts in the season
}

\author{
E Siebald, HF Elizalde, L Goic, M Matzner
}

INIA Department of Animal Production, Remehue Experimental Station, PO Box 24, O Osorno, Chile

\begin{abstract}
In southern Chile, pasture is the most important crop, being the cheapest source of nutrients for the ruminant livestock. At the same time, during the winter months, grass silage is the main feed for the more intensified cattle enterprises. It has been clearly shown that improving the quality of silage used for beef cattle is one of the most effective methods for reducing costs over the winter period (Steen, 1991, ARINI Occ Pub, 20, 19-34).

The experiment was carried out at the Remehue Experimental Station (INIA) in Osorno, Chile $\left(40^{\circ} 35^{\prime} \mathrm{S}\right)$ during the 1993 1994 season. The aim of the trial was to examine the effect of only one or two cuts of silage harvest on the performance of growing cattle.
\end{abstract}

Three hectares of an old permanent grassland of mixed botanical composition, containing Lolium perenne $30 \%$, other grasses (Holcus lanatus, Agrostis spp, Bromus spp) $52 \%$, Trifolium repens $5 \%$ and others $12 \%$, was used in this work. The sward received a total annual fertiliser application of $43 \mathrm{~kg} \mathrm{~N}, 159 \mathrm{~kg}$ $\mathrm{P}_{2} \mathrm{O}_{5}$ and $50 \mathrm{~kg} \mathrm{~K} \mathrm{O}_{2} \mathrm{O}$. Twenty-one young (initial LW $250 \mathrm{~kg}$ ) Friesian bulls were allocated to a randomized block design consisting of three treatments as follows: (A) Conventional onecut system, (early Dec.) with a 70 days cutting interval, (B) First cut silage (early Nov.) with 45 days growth, (C) Second cut silage (mid Dec.) with 45 days regrowth.

Forage dry matter production (ton/ha) at harvest for the three cuts were : $6.4,2.4$ and 4.4 for treatments (A), (B) and (C), respectively.

Overall better performance was achieved with short cutting intervals, with higher $(P \leq 0.05)$ growing rates with these two silages compared to the conventional one.

\begin{tabular}{|c|c|c|c|}
\hline & & Treatment & \\
\hline & A & B & $\mathrm{C}$ \\
\hline Dry matter & 165.4 & 171.1 & 198.3 \\
\hline $\mathrm{pH}$ & 4.21 & 3.90 & 3.88 \\
\hline \multicolumn{4}{|l|}{ Composition of DM } \\
\hline Crude Protein & 118.8 & 185.1 & 144.3 \\
\hline Ammonia $N(g / k g ~ T N)$ & 105.5 & 87.1 & 79.4 \\
\hline$D$ value & 62.04 & 71.23 & 67.23 \\
\hline \multicolumn{4}{|l|}{ Animal performance } \\
\hline Dry matter intake (kg DM/day) & 4.55 & 5.93 & 6.35 \\
\hline Growing rate (kg LW/day) & $0.323^{b}$ & $0.774^{a}$ & $0.826^{a}$ \\
\hline
\end{tabular}

Means with the same superscript, within rows, are not significantly different (Tukey, $P>0.05$ ). 